\title{
PALAEODOSIMETRICAL PROPERTIES OF SODIUM ALKALI FELDSPARS AND PROBLEMS OF LUMINESCENCE DATING OF SEDIMENTS
}

\author{
Galina HÜT a and Ivar JAEK ${ }^{b}$ \\ a Geoloogia Instituut (Institute of Geology), Estonia pst. 7, EE-0001 Tallinn, Eesti \\ (Estonia) \\ b Tartu Ulikooli eksperimentaalfüüsika ja tehnoloogia instituut (Institute of Experimental \\ Physics and Technology, University of Tartu), Tähe 4, EE-2400 Tartu, Eesti (Estonia)
}

Presented by A. Raukas

Received 14 August 1995, accepted 18 December 1995

Abstract. Emission spectra of natural alkali feldspars extracted from sediments are studied using a CCD-camera based high sensitivity spectrometer. Applying a semiconductor laser $(860 \pm 1 \mathrm{~nm})$, two dominant emission bands, blue $(410 \mathrm{~nm})$ and orange $(570 \mathrm{~nm})$, are revealed in infrared optically stimulated luminescence (IROSL) spectra for the most of the sediments from Scandinavian sections. Luminescence and dosimetrical properties of the hole traps, the induced orange emission band typical of sodium alkali feldspars are studied. As a result, high light bleachability but low stability of the dosimetrical information in sodium alkali feldspars are established. Problems of luminescence dating of sediments based on the mixture of potassium-sodium alkali feldspars are discussed.

Key words: luminescence dating, palaeodosimetry, phosphorescence, emission, stimulation, bleachability, dose response, dose reconstruction.

\section{INTRODUCTION}

Alkali feldspars $\mathrm{K}(\mathrm{Na}) \mathrm{AlSi}_{3} \mathrm{O}_{8}$ are widespread natural minerals. During the past decade the scientists have focused their attention on the study of the luminescent and dosimetrical properties of these minerals in order to elaborate luminescence dating techniques for Quaternary sediments.

The main requirements for minerals serving as palaeodosimeters are: (1) high stability of stored age information in the time span essential for the Quaternary sediments; (2) high bleachability of minerals by the natural light for zero-point realization; (3) stability of dosimetrical and luminescent properties of minerals during burial and all laboratory treatments. Minerals are usually extracted by heavy licuid with density $2.58 \mathrm{~g} / \mathrm{cm}^{3}$, and a mixture of sodium and potassium components is obtained due to the isomorphism of the solid solution of $\mathrm{K}(\mathrm{Na}) \mathrm{AlSi}_{3} \mathrm{O}_{8}$. It is practically impossible to separate these two components mechanically. The only way to study their characteristics independently is optical separation based on the difference of their emission spectra.

The spectral characteristics of sodium and potassium feldspars are 
rather well studied (Таращан et al., 1978; Dalal et al., 1988; Kirsh \& Townsend, 1988; Prescott et a1., 1990; Huntley et al., 1991; Jungner \& Huntley, 1991; Spooner, 1993). It is shown that the emission spectra of potassium feldspars have a maximum at $410 \mathrm{~nm}$ (blue), those of sodium feldspars, however, have a very bright luminescence with a maximum at $570 \mathrm{~nm}$ (orange); for fine grains extracted from sediments the orange emission band is dominant.

The potassium component of alkali feldspars (emission about $410 \mathrm{~nm}$ )' is widely used for the dating of Quaternary events up to $150-200 \mathrm{ka}$.

The objective of the following investigation is to detail the palaeodosimetrical properties of the sodium component of alkali feldspars and possible application of this component for luminescence dating.

\section{EXPERIMENTAL}

The samples under study were taken from Finnish, Swedish, and German sections. Alkali feldspars $(100-160 \mu \mathrm{m})$ were extracted from these sediments following the techniques described earlier (Mejdahl, 1983; Hütt \& Smirnov, 1983). Both natural and laboratory-irradiated samples were studied. Laboratory irradiations were performed by $\gamma$-source ${ }^{60} \mathrm{Co}$ or X-ray at room temperature.

The following characteristics of samples were measured:

(1) Spectra of phosphorescence.

(2) Spectra of stimulation.

(3) Infrared optically stimulated $(860 \pm 1 \mathrm{~nm})$ luminescence (IROSL) spectra of natural and laboratory irradiated samples.

(4) Bleachability of luminescence induced by blue and orange centra of recombination.

(5) Dose reconstruction using different emission bands.

(6) IROSL spectra at low and elevated temperatures.

The phosphorescence and OSL spectral studies were performed using

a CCD-camera based high sensitivity spectrometer. All spectra from 200 to $800 \mathrm{~nm}$ are focused simultaneously on a liquid nitrogen cooled CCDcell with $115 \times 298$ pixels. Because of high efficiency ranging from $16 \%$ in the ultraviolet (UV) to $40 \%$ in the inirared (IR) and extremely low background noise of the cell, very weak luminescence may be detected. Depending on the luminous intensity, the signal can be accumulated by the cell for an integration time of $30 \mathrm{~ms}$ up to several hours (Rieser et al., 1994). The procedure for measuring the stimulation spectra was described elsewhere (Hütt et al., 1988). A semiconductor laser with pulse and permanent regime of work $(860 \pm 1 \mathrm{~nm})$ was used as a source of IR light.

Bleaching was performed by the natural diffused light and an artificial daylight simulator with or without the UV component produced by the UVA lamp.

\section{RESULTS AND DISCUSSION}

\section{Phosphorescence spectra and spectra of stimulation}

A phosphorescence spectrum (Fig. 1) reveals the whole set of centra of recombination of charge carriers released from shallow traps. It was measured $1 \mathrm{~min}$ after $\beta$-irradiation. The following measurements carried out during one week after irradiation did not reveal any changes in the shape of the spectra. 


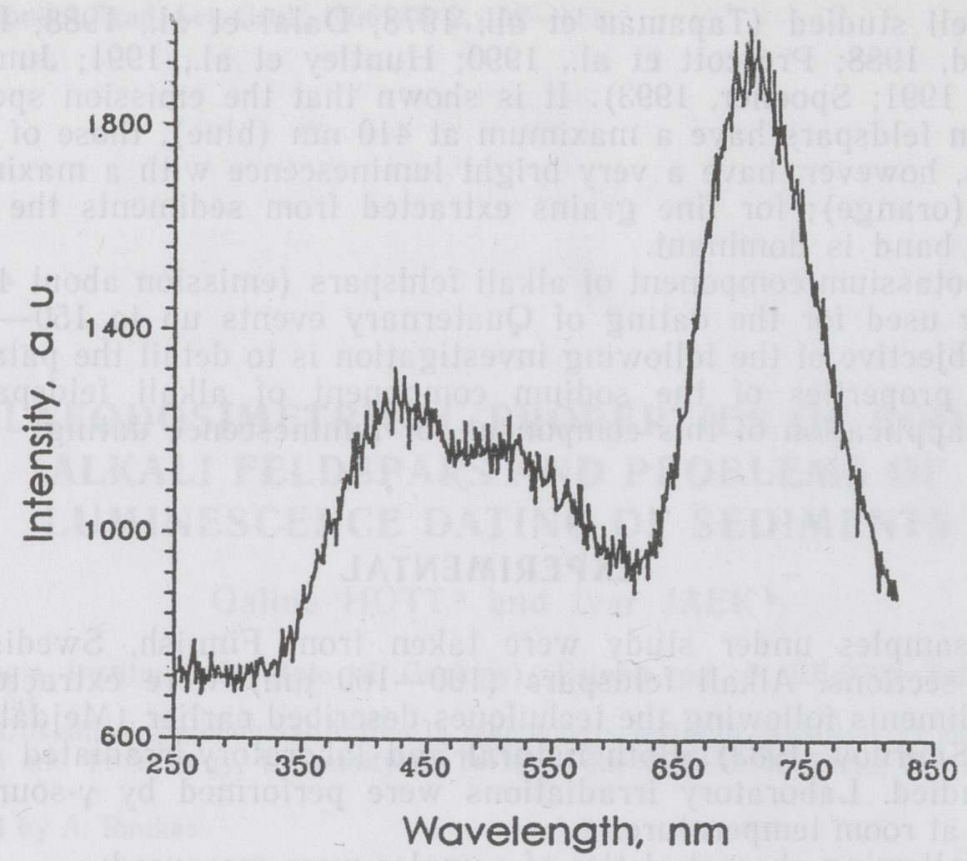

Fig. 1. Spectrum of phosphorescence of alkali feldspars extracted from sediments (sample No. 986) measured 1 min after $\beta$-irradiation using CCD-camera. Spectrum is uncorrected.

Spectra of stimulation for the orange emission band were measured (Fig. 2). It was found out that the traps which induced the maximum at about $900 \mathrm{~nm}$ were the same as for blue emission. The same was also the thermooptical mechanism of OSL for both emission bands (Hütt et al., 1988; Hütt \& Jaek, 1990).

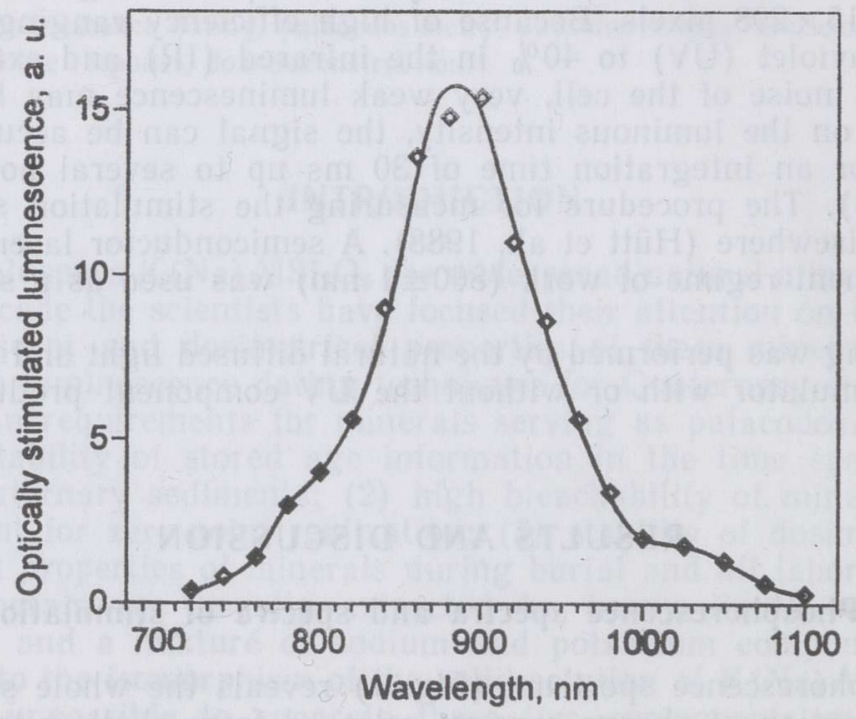

Fig. 2. Spectra of stimulation (IR part) of alkali feldspars, extracted from sediments, for the emission band $570 \mathrm{~nm}$ (filters of USSR production with FWHM $580 \pm_{-30}^{20} \mathrm{~nm}$ ), sample No. 986. 
The IROSL emission spectra consist of two rather well resolved bands at $410 \mathrm{~nm}$ and $570 \mathrm{~nm}$ (Fig. 3). In our research the UV and IR parts of the spectra were cut off by the filter BG-39, avoiding a background signal from the stimulated IR light. The differences registered between the IROSL and phosphorescence spectra may be explained as follows. In the case of $\beta(\gamma)$-irradiation all hole and electron processes are involved,

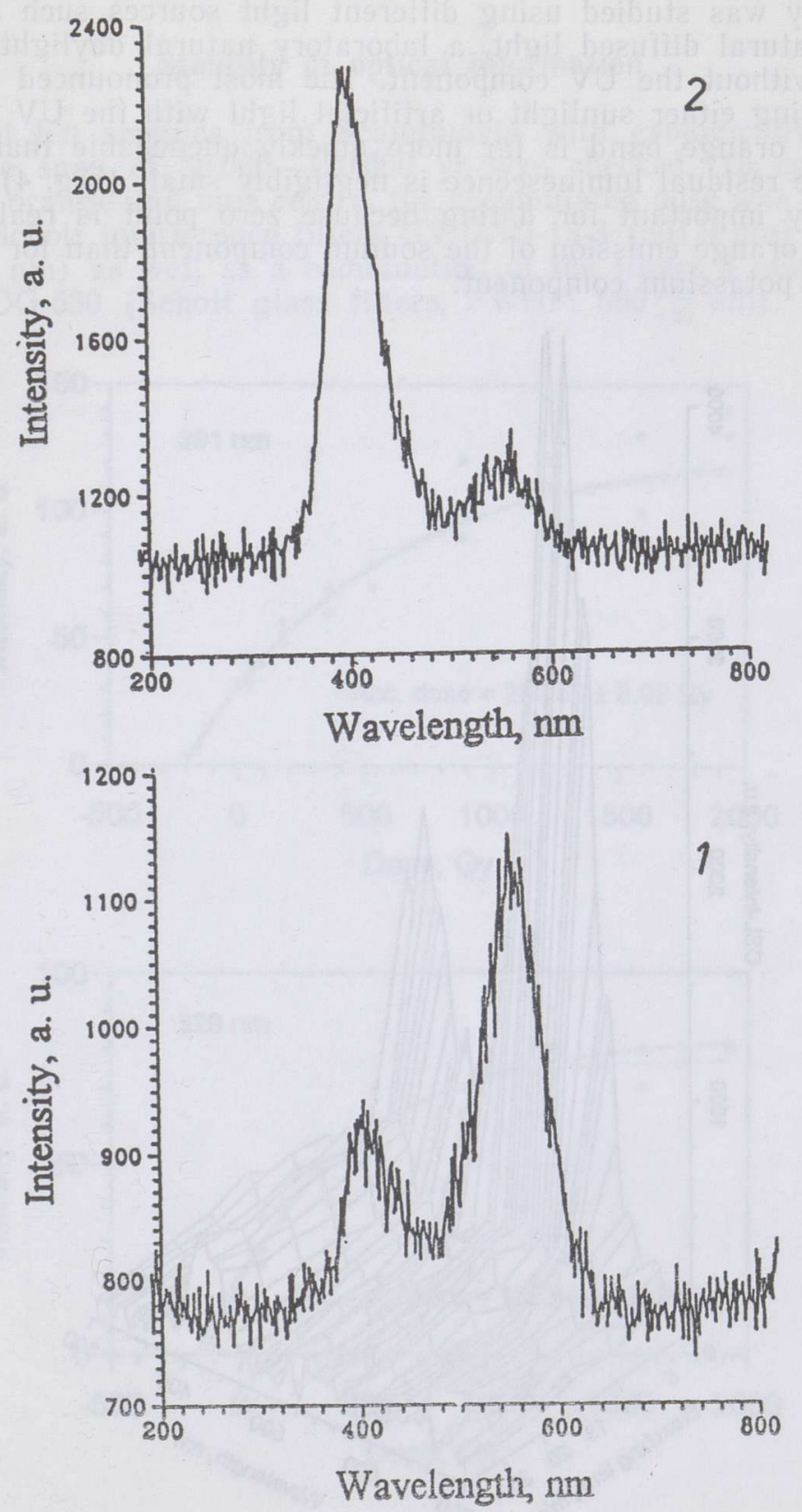

Fig. 3. IROSL spectra of typical alkali feldspars extracted from Scandinavian sections. 1 , sample No. $986, K_{\text {internal }}=10.0 \% ; 2$, sample No. 1022 , K $\mathrm{K}_{\text {interna1 }}=11.8 \%$. Semiconductor laser $860 \pm 1 \mathrm{~nm}$ in pulse mode was used. 
while IROSL spectra, as was shown for the blue centrum of recombination (Jaek et al., 1995), are caused only by electron recombination. It is notable that the above-mentioned spectra (Figs. $1-3$ ) are typical of samples from all Scandinavian and German sections; only the ratio of emission bands is different.

\section{Bleachability}

Light sensitivity of the centra of recombination (blue and orange) or bleachability was studied using different light sources such as natural sunlight, natural diffused light, a laboratory natural daylight simulator with and without the UV component. The most pronounced effect was revealed using either sunlight or artificial light with the UV component added. The orange band is far more quickly quenchable than the blue one and the residual luminescence is negligibly small (Fig. 4). This fact is extremely important for dating because zero point is realized much quicker for orange emission of the sodium component than for blue emission of the potassium component.

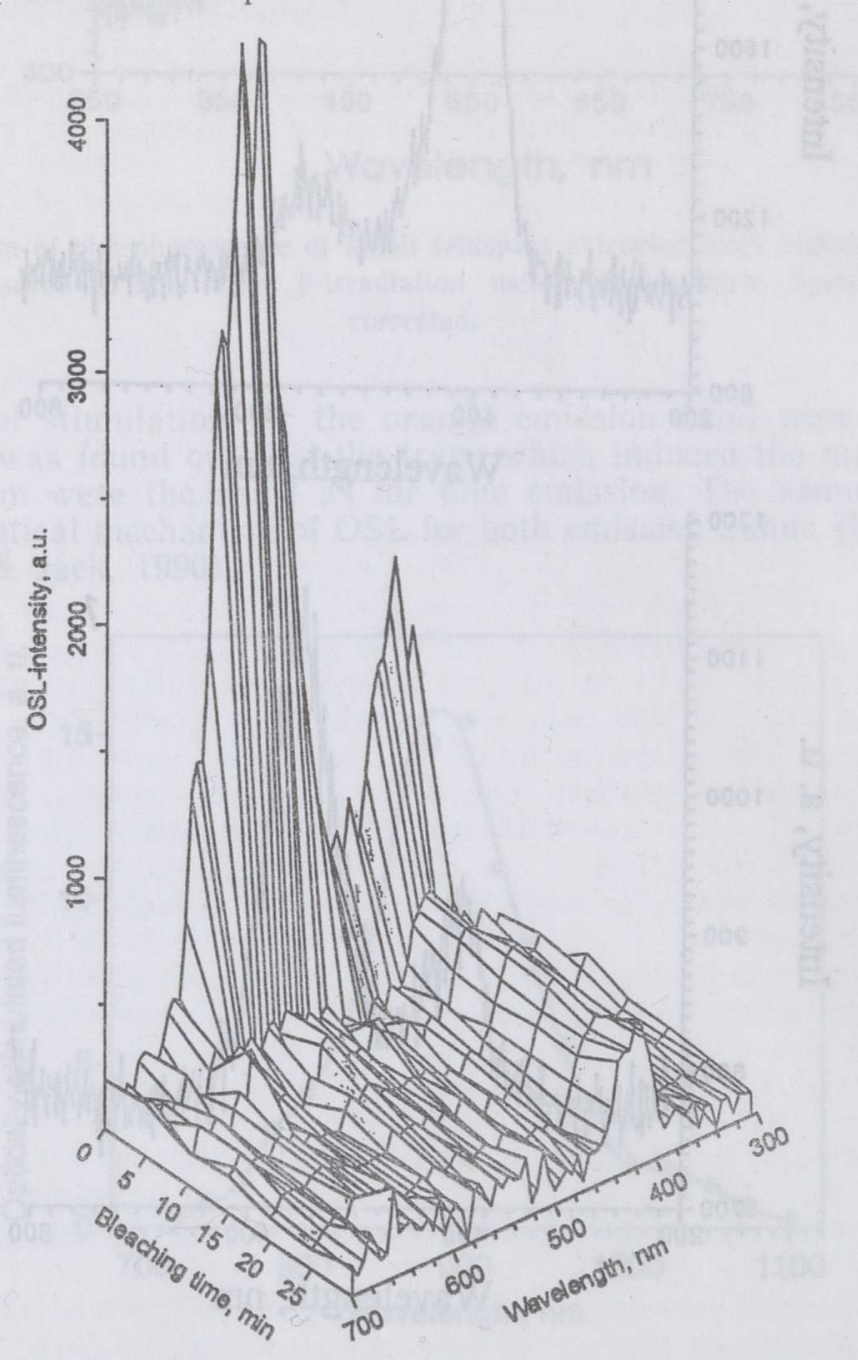

Fig. 4. Effect of OSL bleaching of natural sample by daylight together with the UV component. 
IROSL spectra show no changes with the dosing of samples up to $2 \mathrm{kGy}$. This dose is close to the level of saturation for both sodium and potassium components. The ratio of yellow and blue bands in IROSL spectra stabilized during three weeks after the irradiation and there occurred no changes after $1-5$ years of storing for most of the samples studied. This proves the absence of permanent channels for anomalous fading in the sodium component.

\section{Stability of optical information}

A set of ten samples from Scandinavia with geologically predicted ages in the span of $30000-120000 \mathrm{yr}$ was checked. To compare the stability of orange and blue centra, the accumulated dose was reconstructed using Schott interference filters UV-DAD-15-3 (391.9 nm) and DMZ20-2 (529.1 $\mathrm{nm})$ as well as a combination of the filters $3 \mathrm{~mm}$ BG-39+ +3 mm OG-530 (Schott glass filters, FWHM 560 ${ }_{-25}^{+30} \mathrm{~nm}$ ). The use of

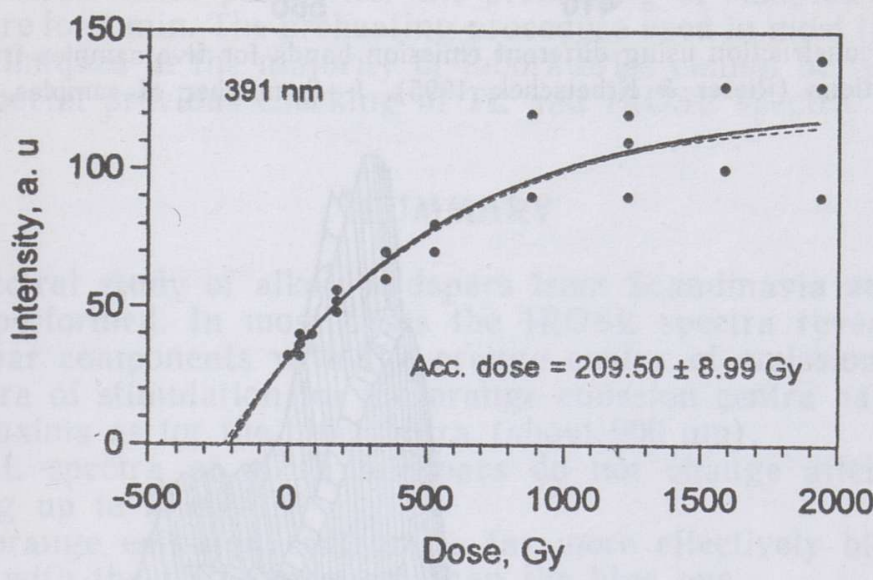

a

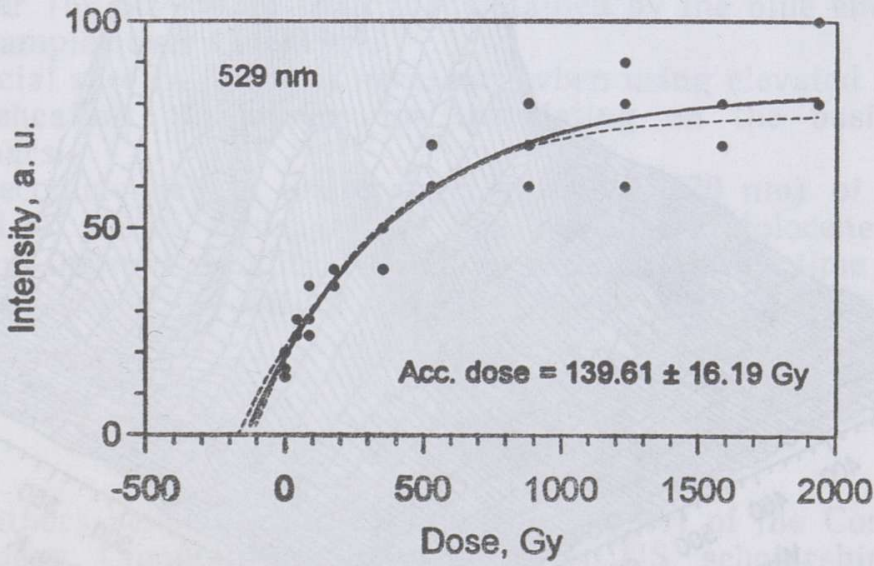

Fig. 5. Accumulated dose reconstruction and age calculation for sample No. 1028 using Schott interference filters: $a$, UV-DAD-15-3 (391.9 nm); $b$, DMZ-20-2 (529.1 nm). Filled circles - experimental data, solid line - exponential fitting, dashed lines - deviations. 


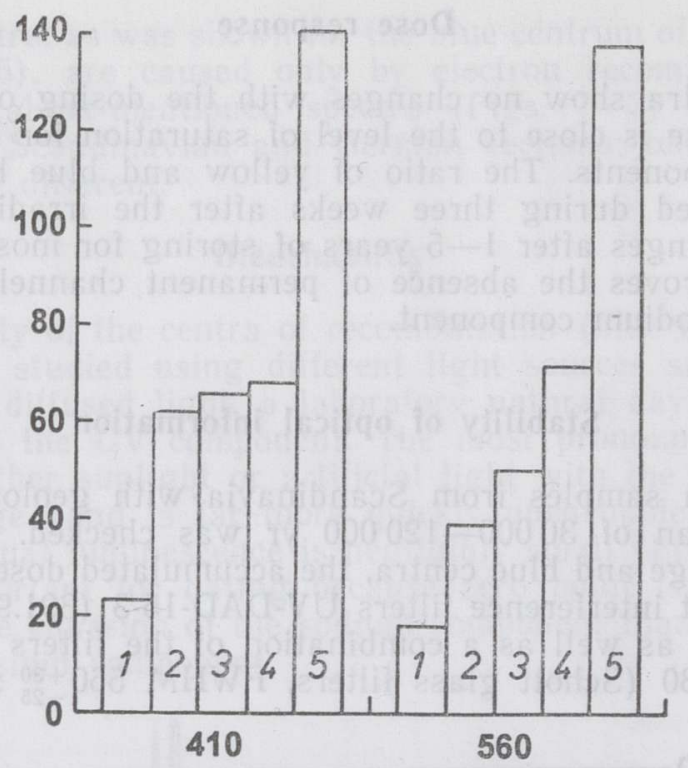

Fig. 6. Dose reconstruction using different emission bands for five samples from German sections (Rieser \& Krbetschek, 1995). 1-5, number of samples.

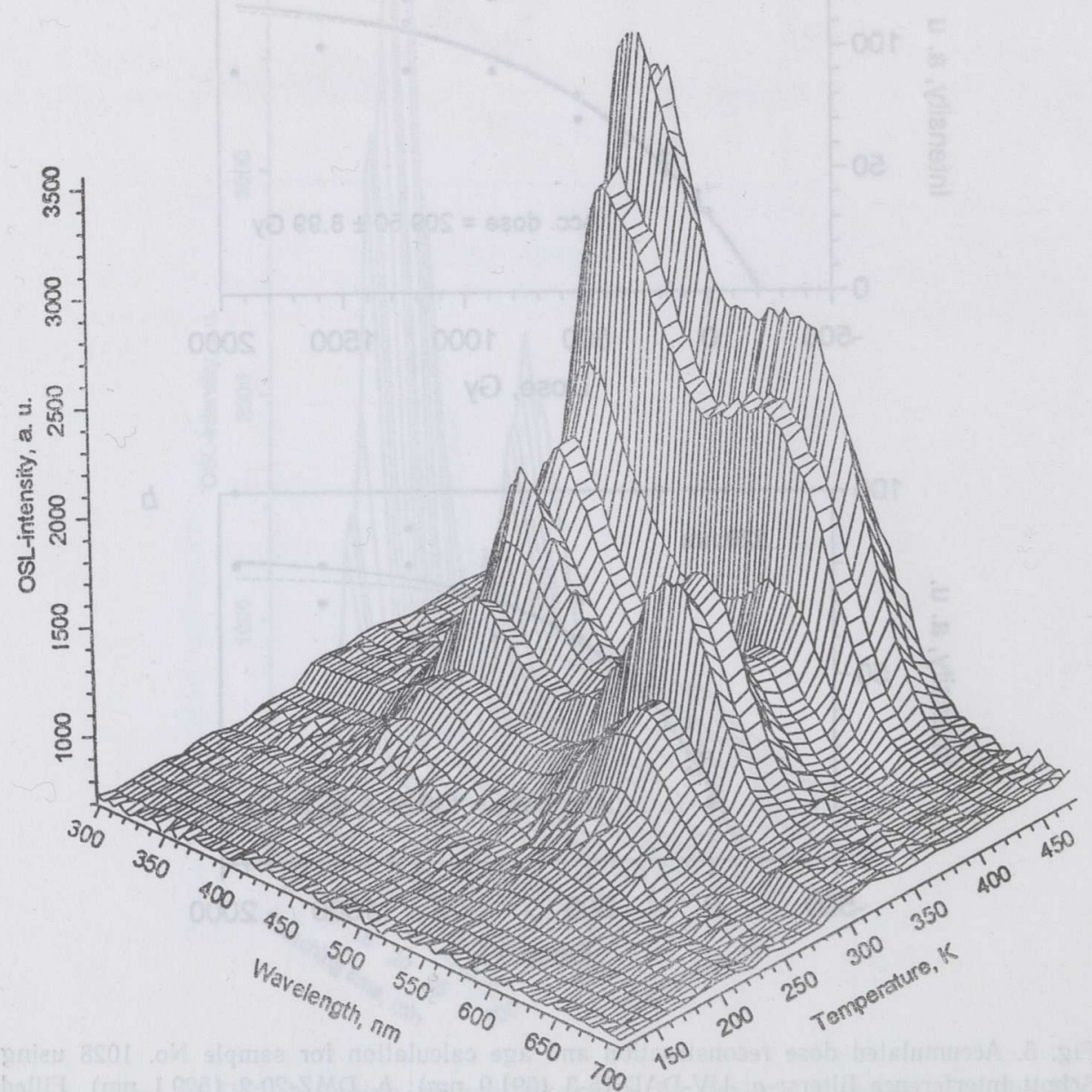

Fig. 7. Three-dimensional IROSL spectrum of alkali feldspars at low and elevated temperatures. Sample No. 986. 
orange emission for dating gave regularly younger ages than that of blue emission (Fig. 5). The same results are illustrated by Fig. 6. Four samples from German sections were measured by using different interference filters allowing separation of sodium and potassium emissions. Various accumulated doses were obtained. The only explanation may be different thermal stability of holes at the orange and blue centra of recombination. By the way, well-known underestimation of luminescence ages for loesses may be explained by the dominance of the orange emission for fine grains used for the dating.

\section{IROSL spectra at low and elevated temperatures}

Complicated IROSL spectra consisting of bands induced by centra of recombination with a different time of half-life of holes should be treated with precaution during laboratory procedures. As one can see from Fig. 7, the IROSL spectra changed at elevated temperature (about $80^{\circ} \mathrm{C}$ ). Redistribution of the intensities of orange and blue emissions is clearly seen in the spectrum. It leads to dramatic change of the palaeodosimeter. The same effect takes place after the preheating of samples at the same temperature for $1 \mathrm{~min}$. The preheating procedure used in most luminescence dating techniques in the majority of laboratories cannot be recommended without special previous checking of TL and IROSL spectra.

\section{SUMMARY}

(1) A spectral study of alkali feldspars from Scandinavia and Germany was performed. In most cases the IROSL spectra revealed sodium feldspar components with the orange centra of emission $(570 \mathrm{~nm})$.

(2) Spectra of stimulation for the orange emission centra have the same IR maxima as for the blue centra (about $900 \mathrm{~nm}$ ).

(3) IROSL spectra of alkali feldspars do not change after laboratory dosing up to 2 kGy.

(4) The orange emission centrum is far more effectively bleachable by light with the UV component than the blue one.

(5) The dose, reconstructed using the orange emission band, is as a rule smaller (by $30-50 \%$ ) than that obtained by the blue emission band (for samples over $15000 \mathrm{yr}$ ).

(6) A special spectral study is necessary when using elevated temperature or preheating of samples for the dating on the basis of alkali feldspars.

It is recommended to use orange emission $(570 \mathrm{~nm})$ of the sodium component of alkali feldspars for the dating of Holocene sediments. Supposedly, thermal stability of holes is enough for this time span, while better resolution of the dating can be achieved through better zero-point realization.

\section{ACKNOWLEDGEMENTS}

The authors acknowledge the financial support of the Commission of the European Communities for COPERNICUS scholarship, Estonian Science Foundation (grant No. 325), and ISF (grant No. LK7100). G. Hütt is grateful to Prof. W. Stolz, U. Rieser, and M. Krbetschek for fruitful collaboration. 


\title{
REFERENCES
}

Dalal, M., Kirsh, Y., Rendell, H., Townsend, P. D. 1988. TL emission spectra of natural feldspar. - Nucl. Tracks Radiat. Meas., 14, 1/2, 57-62.

Jaek, I., Hütt, G., Seeman, V., Brodski, L. 1995. Luminescence and ESR of alkali feldspars doped by probe impurities. - Rad. Meas., 24, 4, 557-564.

Huntley, D., Godfrey-Smith, D., Haskell, E. 1991. Light-induced emission spectra from some quartz and feldspars. - Nucl. Tracks Radiat. Meas., 18, 1/2, 127-131.

Hütt, G., Jaek, I. 1990. Photoluminescence dating of the alkali-feldspars: Physical background, equipment and some results. -- Rad. Prot. Dosim., 34, 1/4, 73-74.

Hütt, G., Jaek, I., Chonka, J. 1988. Optical dating: K-feldspars optical response stimulation spectra. - Quat. Sc. Rev., 7, 381-385.

Hütt, G., Smirnov, A. 1983. Thermoluminescence dating of sediments by means of the quartz and feldspars inclusion methods. - PACT, 9, 463-473.

Jungner, H., Huntley, D. 1991. Emission spectra of some potassium feldspars under $633 \mathrm{~nm}$ stimulation. - Nucl. Tracks Radiat. Meas., 18, 1/2, 125-126.

Kirsh, Y., Townsend, P. D. 1988. Speculation on the blue and red bands in the TL emission spectrum of albite and microcline. - Nucl. Tracks Radiat. Meas., 14, $1 / 2,43-49$.

Mejdahl, V. 1983. Feldspar inclusion dating of ceramics and burned stones. - PACT, 9, 351-364.

Prescott, I. R., Akber, R. A., Gartia, R. K. 1990. Three-dimensional thermoluminescence spectroscopy of minerals. - In: Coyne, L. M., McKeever, S. W. S. and Blake, D. F. (eds.). ACS-Series 415. Chapter 10: Spectroscopic Characterization of Minerals and Their Surfaces, 180-189.

Rieser, U., Krbetschek, M. R. 1995. About the influence of different luminescence emissions on OSL dating. - Rad. Meas., 24, 4, 473-478.

Rieser, U., Krbetschek, M. R., Stolz, W. 1994. CCD-camera based high sensitivity TL/OSL spectrometer. - Rad. Meas., 23, 2/3, 523-528.

Spooner, N. A. 1993. The Validity of Optical Dating Based on Feldspars. Dissertation, Linacre College, Oxford (unpublished).

Таращан А. Н., Максимчук В. Г., Кузнецов Г. В. 1978. Влияние примесей на рентгенолюминесценцию полевых шпатов. - In: Тр. Всесоюз. конф. «Использование люминесценции минералов в геологии». Таллинн, $63-66$.

\section{NAATRIUMPÄEVAKIVIDE PALEODOSIMEETRILISED OMADUSED JA SETETE LUMINESTSENTSDATEERIMISE PROBLEEMID}

\author{
Galina HÜT, Ivar JAEK
}

CCD-kaameral baseeruva kõrgtundliku spektromeetriga on uuritud setetest ekstraheeritud looduslike päevakivide kiirgusspektreid. Suuremal osal Skandinaaviast pärinevail profiilidel esineb pooljuhtlaseri (860士 $\pm 1 \mathrm{~nm})$ abil optiliselt stimuleeritud luminestsentsis kaks domineerivat kiirgusriba - sinine $(410 \mathrm{~nm})$ ja oranž $(570 \mathrm{~nm})$. On uuritud Na-päevakivi puhul tüüpilise oranži kiirgusribaga seotud auktsentrite luminestsentsi ja dosimeetrilisi omadusi. Na-päevakividel on hea väljakiiritatavus, kuid madal dosimeetrilise informatsiooni stabiilsus. On analüüsitud probleeme, mis tekivad setete dateerimisel K- ja Na-segapäevakivide abil. 


\title{
ПАЛЕОДОЗИМЕТРИЧЕСКИЕ СВОЙСТВА Nа-ПОЛЕВЫХ ШПАТОВ И ПРОБЛЕМЫ ЛЮМИНЕСЦЕНТНОГО ДАТИРОВАНИЯ ОТЛОЖЕНИЙ
}

\author{
Галина ХЮТТ, Ивар ЯЭК
}

Исследованы спектры излучения природных щелочных шпатов, экстрагированных из отложений, при помощи CCD-камеры, сопряженной с высокочувствительным спектрометром. В образцах щелочных полевых шпатов, экстрагированных из отложений скандинавских разрезов, в спектре люминесценции, стимулированной инфракрасным светом, обнаружено две полосы излучения: голубая (410 нм) и оранжевая (570 нм). В качестве источника стимуляции использовался полупроводниковый лазер ( $860 \pm 1$ нм). Исследованы дозиметрические свойства дырочного центра рекомбинации, индуцирующего оранжевое свечение (570 нм), типичное для Na-полевых шпатов. Обнаружена существенно большая чувствительность к свету и значительно меньшая остаточная светосумма, чем это было известно для К-полевых шпатов. Однако стабильность сохранения дозиметрической информации в случае $\mathrm{Na-полевых} \mathrm{шпатов}$ ниже. Оббуждаются проблемы люминесцентного датирования отложений на базе смеси $\mathrm{K}-\mathrm{Na-полевых} \mathrm{шпатов.}$ 